\title{
The Application of Thematic Progression Pattern in the Teaching of English-Chinese Text Translation
}

\author{
Shifang Li \\ School of Languages and Cultures, Shanghai University of Political Science and Law, China
}

\begin{abstract}
This paper analyzes Thematic Progression pattern and its role in the process of text translation, providing a new perspective for the current translation teaching. TP pattern can be used as a reference object before translation to avoid the translator's mistakes in information transmission; after translation, it can also be a means to test the cohesion and coherence of the translation. In order to preserve the style of the original text, it is necessary to maintain the same TP pattern as the source text in translating activity, which is the foothold of this research. Therefore, the article proposes that in English-Chinese translation, the same TP pattern as the source text should be maintained as much as possible, in order to achieve the purpose of retaining the original style. Nevertheless, all this is based on the premise that the meaning of the original text will not be misunderstood.
\end{abstract}

Index Terms - thematic progression pattern, English-Chinese text, teaching of text translation

\section{INTRODUCTION}

Based on Danes' TP theory and Halliday's thematic theory, the linguists all over the world have done many researches on TP patterns.

The concept of theme and rheme is first put forward by the Prague School linguists. Mathesius, the founder of the Prague School, first put forward the notions of theme and rhyme in 1939. Halliday (1967, 1985) accepts and develops the theory of the Prague school. Halliday (1985) holds that theme refers to the given information between the two communicators, from the perspective of information structure, and usually in the first position of the clause, while rheme, following the theme, is the unknown or new information presented by the speaker. "Theme and rheme" and "given information and unknown information" are two kinds of concepts, and the former is speaker-oriented while the latter is hearing-oriented. Chinese scholar, Xu Shenghuan (1985) proposes that theme does not always refers to the given information, and it may also represent part of given information, relevant information, new information or function as a guiding role.

Based on the studies of theme and rheme, many scholars, both in China and abroad, carried further studies on thematic structures in terms of textual structure and then put forward the theory of TP. The notion of thematic progression is first put forward by Frantisek Danes from the aspect of text analysis. Danes suggests that thematic progression refers to the selection and arrangement of themes and rhemes, the inter-relations and the relations between theme and rheme in the preceding clause (Danes, 1974).

In the accordance with the prevenient researches, especially the Thematic Progression theory proposed by Danes (1974), many linguists and scholars start to explore the organization methods and progression patterns of the text on balance. They have put forward their own views on the thematic progression patterns. It is Danes (1974) that enlarges the study range of theme and rheme into the textual level and postulates five Thematic Progression patterns. And then Four patterns are presented by Huang Yan (1985) concludes six patterns. Hu Zhuanglin (1994) provides three major TP patterns. As for the classification of thematic progression pattern, different researches insist on different ideas. However, all these scholars research the thematic progression patterns from the aspect of text level.

As one of the important tools for text analysis, the thematic progression theory in linguistics plays a guiding role both in interpretation and translation of original text during translation activities. And in question of whether the translation should follow the thematic progression mode of original text, there are two situations (Baker, 1992).

One is that the translator can retain the mode of original text without distorting the target discourse, and the other situation is that if the translator does not want to distort the target language, then the progression mode of the original text must be adjusted, just as Nord mentioned — it is the theory that make translation could be taught (Nord, 1997).

\section{Application of Thematic Progression Pattern in English-Chinese Text Translation}

The theme and rheme in a text do not appear in isolation. They are always closely related to each other. As the theme of each sentence advances forward, the entire text gradually unfolds until a coherent text is formed. The coherence of the textual meaning is manifested in many aspects in the language form (Zhu yongsheng \& Yan shiqing, 2001). 
However, in terms of the information structure and level of a text, thematic structure is still one of the important textual mechanisms. As the theme of each sentence moves forward, the whole text expands gradually until it forms a whole that can express a complete meaning. Therefore, the study of thematic progression pattern is one of the important methods to study text coherence and text composition. By grasping the thematic progression pattern of the original text, we can not only analyze how the whole text is unfolded, cohesive and coherent, but also fully understand the distribution of the information of the central content in the text, which can be used by translators to avoid mistakes in information transmission and make the translation more reasonable and smoother.

Regarding the classification of thematic progression patterns, many scholars have made quite fruitful research results. But no matter how classified, deconstructing the thematic progression pattern of the source text can enable us to better understand the textual structure of the text, so as to ensure the accuracy of the translation, as well as the cohesion and coherence of the paragraphs.

This paper will analyze the application of three most commonly used thematic progression patterns in text translation, and give examples to prove their importance in translation.

\section{A. Parallel Pattern}

Taking the theme $(\mathrm{T})$ of the first sentence as the starting point, the following sentences will use the theme of this sentence as the main theme, leading to different rhemes $(\mathrm{R})$ respectively, and revealing and elucidating the same theme from different angles. That is to say, in this pattern, every clause takes the theme of the first clause as the theme and has different rhemes. Many examples of this pattern can be found in both English and Chinese. Therefore, it is not difficult to keep the target text the same as the original text during translation. Its mode is shown in the figure:

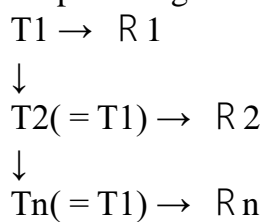

Example 1: My aunt Jennifer is an actress. She must be at least 35 years old. In spite of this, she often appears on the stage as a young girl. Jennifer will have to take part in a new play soon. This time, she will be a girl in a new play soon. In the play, she must appear in a bright red dress and long black stockings. Last year in another play, she had to wear short socks and a bright, orange-colored dress. (Alexander L G 1991, p93)

Example 1 is a more typical thematic text. It uses my aunt Jennifer as the main theme to start the narration of the story. All the following sentences take the same element as the starting point for discussion, and the rheme of each sentence makes a new exposition on this starting point or supplement. The reader can be said to have a clear view of the topic the author is talking about, so the coherence of the translation will not be affected as long as the translation follows this parallel mode of progression.

Reference Translation:

我的詹妮弗姨妈是一位女演员。她至少有 35 岁了。尽管如此, 她在舞台上经常扮演少女。詹妮弗不久将参 演一出新戏。这一次, 她将扮演一个 17 岁的姑娘。演戏时, 她必须身着大红衣裙和黑色长袜。去年演另一出 戏时, 她不得不穿短袜和一条色彩鲜艳的橘红衣裙。

\section{B. Concentrated Pattern}

Concentrated Pattern refers to different theme and same rheme. Its mode is shown in the figure below:



Example 2: When I go into a bank I get rattled. The clerks rattle me; the wickets rattle me; the sight of the money rattles me; everything rattles me. (Lu Jun, Hou Xiangqun 2001, p.135-147)

Reference Translation: 我走进银行就心里发慌。办事员使我心里发慌; 柜台窗口使我心慌; 我看到钱也心慌; 一 切都使我心慌。

The theme of the text example 2 above is different, and the rheme is the same. The author of the original text deliberately adopted the structure of repeating the same rheme. The purpose is obvious. It can make readers immediately think of the author's situation at the time, and fully express the author's very nervous and embarrassed mood in the bank at that time. Therefore, the translation should also be carried out according to the thematic progression mode of the original text.

If translated as: 我走进银行就心里发慌。办事员、柜台窗口、钱, 所有的一切都让我心慌。

Although the meaning of the translation is correctly conveyed, the vivid depiction of psychology in the original text is completely discarded, which completely fails to reflect the tension and fear of the author at that time. 


\section{Derivative Pattern}

After the theme and rheme of the first sentence are described, the main sentence of each subsequent sentence is derived from a certain part of the rheme of the first sentence, that is, the rheme or part of the rheme of the previous sentence becomes the theme of the latter sentence. As shown in the figure below:

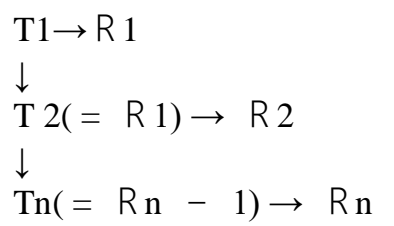

Example 3: 我怎能忘记那美丽的校园呢? 那儿处处是碧绿的芳草。绿草中铺着洁白的、笔直的石路。 路两旁种的那些树分明是一品红, 然而原该为大红色的排列为环状的叶, 却变为柔媚的粉红, 还有着淡 绿色的边儿。(Qiao Ping 2002, p.40-84)

Example 3 is a lyrical short essay. At first, I recalled the campus, from the campus to the fragrant grass on the campus, and then the fragrant grass leads to the stone road, and the stone road leads to the poinsettia and their leaves beside the road. The progression of theme-rheme layers was clear at a glance. Therefore, the development of the translated text and the organization of information should also follow the same structural pattern as the original text, so as to preserve the integrity and coherence of the text and make the translated text appear smooth and fluent. The following translation better reflects the original text:

How can I ever forget the beautiful campus? The grounds were covered with dark green grass through which stretched a straight white stone path. On both sides of the path were planted what I believed to be poinsettias. Now the flowers were surrounded by pinkish leaves instead of bright red ones as they should have been. (Qiao Ping 2002, p.40-84)

\section{Enlightenment of Thematic Progression PATtern to the Teaching of English-Chinese TeXt Translation}

People use language as a tool to communicate, not in words or single sentences. Sentence is only the smallest unit in verbal communication. In actual communication, people use these sentences to form texts. The so-called text is a sentence chain composed of sentences. These sentence chains can form sentence groups, sentence segments and form a complete text at most. That is to say, sentences have the function of gathering sentences into a text. But there are certain rules to follow, and different ways of organization can convey different meanings (Zhu yongsheng \& Yan shiqing, 2001).

At present, the translation textbooks used by many Chinese universities will enable students to learn and master the eight commonly used translation skills: retranslation, addition and subtraction, part-of-speech conversion, reverse translation and so on. The teacher's teaching only focuses on the translation of words and sentences, and ignores the analysis of the whole text. Although students have mastered the translation methods of words and single sentences, when facing the translation of a paragraph or a text, the translation results are often unsatisfactory, the cohesion between sentences is not close, and the semantics of the whole text is incoherent everywhere.

Baker (1992) once pointed out that the thematic progression pattern of the original text should be reproduced in a certain appropriate way in the translation. If we do not pay attention to this, it may lead to the problem of poor information flow in the translation. In other words, because the thematic progression pattern of all clauses in the original text reflects the purpose and overall effect of the source text, in order to achieve the textual effect similar to the source text, the translator should try his best to reproduce this textual structure in translation.

Through the analysis of the three thematic progression patterns in text translation in section II, we can be sure that the analysis of the thematic progression patterns of the original text can enable us to better grasp the textual structure of the source text, so as to ensure the accuracy of the translation, as well as the cohesion and coherence of the target text. In the actual translation teaching process, in addition to the translation skills of words and sentences, we should also pay attention to the development of the information in the text and the pattern of thematic progression. English is a hypotaxis language while Chinese is a parataxis language. The two languages have different syntactic structures. Moreover, Both English and Chinese texts usually use a variety of different text patterns to develop their text structures. Therefore, in translation teaching, teachers need to remind students that in translation practice, it is determined by the specific information structure of the original text whether the translated text follows the text pattern of the original text, and must not copy the text pattern of the source text.

Generally speaking, the translator should retain the thematic progression pattern of the source text in the target text. Because, English and Chinese languages have their own language characteristics. Moreover, the thematic progression patterns used in English and Chinese texts are complicated. The translator needs to make necessary adjustments or reconstructions according to the actual situation, and express the source text information in a unique language structure and thematic progression pattern consistent with the target text.

\section{A. Retain the Thematic Progression Pattern of the Source Text}

The development of theme rheme between sentences in a text basically follows the above patterns. This feature not 
only constitutes the element of text as a communication unit, but also makes it an important factor as a translation unit. Because human thinking has basically the same pattern. If they are destroyed in translation, the translation will not conform to communicative habits. We will analyze the following three examples respectively.

Example 4:

长安城内街道宽广笔直, 主要大街宽度都在一百米以上, 宫门前的一条东西向的大街, 足有二百二十米 之宽。道路两旁种有青槐和榆树, 并有完整的排水系统。(Lv Ruichang 1983, p.96).

The translation is: The streets were straight and wide. The avenues were over $100 \mathrm{~m}$ in width. The one outside the palace, running from east to west, was fully $220 \mathrm{~m}$ wide. Ash and elm trees lined the streets, all of which had a sewerage system.

This paragraph introduces the situation of Chang'an Street, so the known information (Theme) is the same, that is, "street". The same theme leads to different rheme, which is equivalent to the above variant of $\mathrm{T} 1 \rightarrow \mathrm{R} 1, \mathrm{~T} 1 \rightarrow \mathrm{R} 2, \mathrm{~T} 1$ $\rightarrow$ R3 pattern, but the translation destroys this pattern, and selects the unknown information as the Theme in the third sentence, which makes the third sentence logically unreasonable and confusing in meaning. Therefore, the original translation should be changed as follows:

The streets in Chang'an were straight and wide, with the main streets over $100 \mathrm{~m}$ in width, and the one in front of the palace, running from east to west, even $220 \mathrm{~m}$ wide. All of them were lined with locust and elm trees on both sides and equipped with drainage system.

Similar examples are also common in English-Chinese translation, such as example 5: Mrs Cox (T1) / teaches English in a high school in San Francisco, a big city on the west coast in the United States.(R1) She (T1)/ had wanted to become a teacher when she was young. (R2) She (T1) / has taught eight years now and always enjoyed her work.(R3) (Zhang Peiji 2009, p57).

There are three sentences in example 5. The cohesive relation of their theme and rheme adopts a parallel pattern. If the translation does not follow this pattern, it will affect normal communication, such as: 考克斯女士在旧金山市的一 所中学教英语。它是美国西海岸的一座大城市。她年轻时就想成为一名教师。她已教了八年书, 而且一直很喜 欢自己的工作。

The inappropriateness of this translation lies in the fact that it adds a new theme-rheme structure: "It (San Francisco) is a big city on the West Coast of the United States", which destroys the parallel pattern of Ms. Cox as the theme in the whole paragraph. If it is changed to: 考克斯女士在美国西海岸的大城市旧金山的一所中学教英语。她年轻时就想 成为一名教师。她已教了八年书, 而且一直很喜欢自己的工作。

In this way, the translation will be smooth and natural, in line with the law of thinking in communication. This shows that from the perspective of communication, we must also look at the entire segment as a whole. Because the arrangement of the theme-rheme of each sentence in a paragraph is orderly, if we do not take into account the whole and only consider the situation of each sentence, we are likely to translate a group of scattered sentences that lack integrity. In this case, although there is no problem at the sentence level, it is insufficient at the paragraph level.

Example 6:

Studies serve for delight, for ornament and, for ability. Their chief use for delight is in privateness and retiring; for ornament, is in discourse; and for ability, is in judgment and disposition of business. (Zhang Peiji 2009, p. 107).

The above example 6 text is selected from Bacon's On Reading, which is a more typical derivative thematic progression pattern. In the first sentence, studies (theme 1) is followed by three parallel rhemes: serve for delight (rheme 1), for ornament (rheme 2) and for ability (rheme 3). Then, the author expands the three parallel rhemes respectively to serve as known information (i.e. theme), forming three new theme-rheme structures that are actually parallel, namely, for delight (Theme 2) $\rightarrow$ is in privateness (rheme 2), for ornament (Theme 3 ) $\rightarrow$ is in discourse (rheme 3), for ability (theme 4) $\rightarrow$ is in judgment (rheme 4). Mr. Wang Zuoliang, a famous Chinese translator, also followed the thematic progression pattern adopted by the original author in his translation and translated it as: 读书足 以怡情, 足以博彩, 足以长才。其怡情也, 最见于独处幽居之时; 其博彩也, 最见于高谈榈论之中; 其长才也, 最见于处世判事之际。

Mr. Wang Zuoliang's translation well retains the thematic progression pattern of the original text, skillfully reproduces the information structure of the original text, faithfully conveys the information of the original text, advances layer by layer, and reads well.

\section{B. Reconstruct or Transform the Thematic Progression Pattern of the Source Text}

It is impossible for people to always follow the thematic structure of the original text when translating. When possible, the target language can be close to the original text as much as possible. However, due to the differences between the two languages in word order, sentence focus and natural wording and other aspects, thematic progression patterns of the original text has to be abandoned sometimes. It is important that the translation should have its own thematic progression patterns, read naturally and smoothly, and do not damage the information structure of the original text as well.

Nida \& Taber (1969) once said that every language has its own characteristics. In order to communicate effectively, 
we must follow the characteristics of each language. Effective translators will not impose the morphological structure of one language on another, but make necessary adjustments at any time to express the information of the source language in the unique structure of the target language.

Example 7: We (T1)rounded just such a cape (R1) toward sunset, the most easterly point (R2) of a continent, dramatically high and lonely, a great purple mountain (R3) overhung by a great purple cloud. (Zhang Peiji 2009, p.216).

Reference Translation: 将近落日时分, 我们(T1) 正好绕过这样一个海角 (R1)。这海角 (T2/R1) 位于大陆最东端, 挺拔元立, 引人注目。这(T2)是一座紫红色的大山(R3), 笼罩在一大片紫红色的云雾中。

In example 7, the original sentence contains two appositive phrases, which belong to the relation of parallel theme and rheme. The translation includes the super-sentence body of three clauses. Theme and rheme are connected by continuity and parallelism, and their logical relations are equivalent. If the third sentence is translated into: “一大片紫 红色的云彩笼罩着一座紫红色的大山” Looking at this sentence in isolation, translating the post-attributive past participle overhung into the active voice and the agent cloud into the subject has not changed the meaning of the deep sentence, and the surface sentence is also authentic. However, from the perspective of textural coherence, the information of theme and rheme in this sentence is new, sudden and irrelevant to the previous sentence. The relationship between 'a great purple mountain' and 'a cape' is undistinguished, and it also distorts the original meaning. Therefore, the deep level of the text is not equivalent.

Due to the differences in the general rules of organizing sentences between English and Chinese, Li and Thompson are believed that English is a language with a prominent subject, while Chinese is a language with a prominent topic. Therefore, compared with English, Chinese has a more obvious feature in the overall sentence structure: when the topic in Chinese is very obvious in a certain context, the topic can be omitted. Especially when a paragraph forms a topic chain. This pattern is most common in narrative articles. For example, a concentrated narration of someone in a novel:

Example 8: 靠后壁平铺的板上迭着被裖, 一个二十五六的人躺在上面。他虽然生长在水乡, 却似乎 害着先天的晕船病, 只要踏上船头, 船身晃几晃, 便觉得胃里作泛, 头也晕起来。这一回又碰到逆 风, 下午一点钟上船时便横下来, 直到现在, 还不曾坐起来。躺着, 自然不觉得什么; ....... (Ye Shengtao 1962, p106)

Reference Translation: Against the rear partition was a makeshift bunk of planks and bedding with a young man of twenty-five or six lying on it. Though born and bred a fen man, he seemed to be afflicted with congenital sea-sickness, for he had only to set foot on the swaying deck of a boat and at once his stomach would begin to reel. To make things worse, they were making this journey against a head-wind, and from the moment he had come aboard at one o'clock that afternoon until now he had been stretched out on the bunk and had not sat up once. Naturally enough, he did not feel anything all the time he was lying down... (Barnes, \& A. C. 1958 , p.97)

The four sentences in example 8 form a topic chain, jointly narrating the same topic "a person of twenty-five or six." In the second sentence, a pronoun " $h e$ " is used to express the topic, which makes the topic of the whole paragraph more obvious, and the topics in the third and fourth sentences are omitted. In the English translation of these two paragraphs, the personal pronouns that appear in the subject position cannot be omitted.

Therefore, in order to improve the quality of the translated language and get rid of the translation tone, it is necessary to make great efforts to transform the structure of the two languages, whether it is from Chinese to English or from Chinese to English, otherwise it will not only affect the nature and fluency of the translated text, but also lead to the distortion and unfaithfulness of the translation to the meaning expression of the source language.

There are many patterns of thematic progression, and the development of text is more complicated. As example 9, “曲曲折折的荷塘上面, 弥望的是田田的叶子。叶子出水很高, 像亭亭的舞女的裙。层层的叶子中间, 零星地点缀着些白花, 有舆娜地开着的, 有羞涩地打着朵儿的; 正如一粒粒的明珠, 又如碧天里的星星, 又如刚出浴的美人。微风过处, 送来缕缕清香, 仿佛远处高楼上渺茫的歌声似的。这时候叶子与花也有 一丝的颤动, 像闪电般, 雬时传过荷塘的那边去了。叶子本是肩并肩密密地挨着, 这便宛然有了一道凝 碧的波痕。叶子底下是脉脉的流水, 遮住了, 不能见一些颜色; 而叶子却更见风致了” (Yang Ping 2004, p.206)

In example 9, this text begins with lotus pond $\mathrm{T} 1$ leading to lotus leaf $\mathrm{R} 1$, and then lotus leaf $\mathrm{T} 2$ (= $\mathrm{R} 1$ ) leading to lotus flower R2, which belongs to the third continuation pattern of thematic progression above in this paper. The descriptions of lotus flowers and the descriptions of lotus leaves at the end, including the water led by lotus leaves, all belong to $\mathrm{T} 1 \rightarrow \mathrm{R} 1$. T2 $(=\mathrm{T} 1) \rightarrow \mathrm{R} 2$, the first parallel pattern. In addition, other messages such as the breeze, the fragrance of lotus and other information are interspersed in the middle. From this we can see that most texts usually adopt a variety of thematic progression patterns for interactive and comprehensive use. Therefore, in the actual translation, the translation will be flexible and changeable, and the step-by-step process will often only bring about the effect. The translator should make necessary adjustments or reconstructions at any time according to the situation of the specific text, and express the source text information in the form of language structure unique to the target language, so as to construct a standard and authentic translation. 
Reference translation: As far as eye could see, the pool with its winding margin was covered with trim leaves, which rose high out of the water like the flared skirts of dancing girls. And starring these tiers of leaves were white lotus flowers, alluringly open or bashfully in bud, like glimmering pearls, stars in an azure sky, or beauties fresh from the bath. The breeze carried past gusts of fragrance, like the strains of a song faintly heard from a far-off tower. And leaves and blossoms trembled slightly, while in a flash the scent was carried away. As the closely serried leaves bent, a tide of opaque emerald could be glimpsed. That was the softly running water beneath, hidden from sight, its colour invisible, though the leaves looked more graceful than ever. (Yang Ping 2004, p.206-207)

Therefore, when translating, students should not always stay in the study of the translation of words and single sentences. They should also fully consider the expansion of the whole text and the progression of information, and clarify the connections between sentences, so as to make the whole translation smooth, natural cohesion and coherence.

\section{CONCLUSION}

Because thematic progression pattern can reflect the framework of the text structure, and the development of the thematic progression pattern is relatively complex, it does not follow the same pattern. Therefore, a careful study of this proposition is of great benefit to translation work. This article explores the relationship between thematic progression pattern and the mutual translation of English and Chinese texts from the perspective of text translation, which is very valuable.

We hold that in the translation between English and Chinese, we should try our best to maintain the same thematic progression pattern as the source text, so as to preserve the style of the original text and the meaning that the original author wants to express. However, all this is based on the premise that the meaning of the original text will not be misunderstood, that is, in order to achieve functional equivalence, some necessary adjustments will be made to conform to the marked thematic structure in the source text, so as not to affect the language structure of the target language. This paper is a meaningful attempt to explore the mechanism of intercultural textual meaning transformation by using thematic progression pattern. Here, we can affirm the role of thematic progression pattern in text translation teaching.

\section{REFERENCES}

[1] Alexander L G. (1991). New Concept English. Hefei: Anhui Science and Technology Press.

[2] Baker, M. (1992). In Other Words: A Coursebook on Translation. London: Routledge.

[3] Barnes, \& A. C. (1958). Ni huan zhi (倪焕之). Foreign Languages Press.

[4] Danes, F. (1974). Functional sentence perspective and the organization of the text. In F. Danes (ed.). Papers on functional sentence perspective. Hague: Mouton.

[5] Halliday, M.A.K. (1967/01/01). Notes on Transitivity and Theme in English. Journal of Linguistics, VL 3. 177-244.

[6] Halliday, M. A.K. (1985). An Introduction to Functional Grammar. London: Edward Arnold.

[7] Huang Yan. (1985). On English Theme and Rheme. Foreign Languages (5): 32-36

[8] Hu Zhuanglin. (1994). Cohesion and Coherence in Discourse. Shanghai: Shanghai Foreign Language Education Press.

[9] Lu Jun, Hou Xiangqun. (2001). English-Chinese Translation Course. Shanghai: Shanghai Foreign Language Education Press.

[10] Lv Ruichang. (1983). A course of Chinese-English Translation. Shaanxi People's Publishing House.

[11] Nida, E.A. \&C.R. Taber. (1969). The Theory and Practice of Translation. Leiden: United Bible Societies.

[12] Nord, Christiane. (1997). Translating as a Purposeful Activity: Functionalist Approaches Explained. New York: Routledge.

[13] Qiao Ping. (2002). 108 Masterpieces of Prose. (Chinese-English·English-Chinese). Yilin Publishing House.

[14] Xu Shenghuan. (1985). On Theme and Rheme Again. Foreign Language Teaching and Research, (4): 19-25.

[15] Yang Ping. (2004). Fine Translation of Masterpieces. Qingdao: Qingdao Publishing House

[16] Ye Shengtao. (1962). "Ni Huanzhi 2 Edition” People's Literature Publishing House.

[17] Zhang Peiji. (2009). English-Chinese Translation Tutorial-Revised Edition. Shanghai Foreign Language Education Press.

[18] Zhu Yongsheng. (1995). Thematic progression model and discourse analysis. Foreign Language Teaching and Research (3): 6-12, 80.

[19] Zhu Yongsheng \&Yan Shiqing. (2001). Multidimensional Thinking on Functional Linguistics. Shanghai: Shanghai Foreign Language Education Press.

Shifang Li was born in Harbin, China in 1967. She received her PH. D degree in English Language and Literature from Northeast Normal University, China in 2008.

She is currently a professor in the School of Languages and Cultures, Shanghai University of Political Science and Law, Shanghai, China. Her research interests include Forensic Linguistics, text analysis and Pragmatics Linguistics.

$\mathrm{Dr}$. $\mathrm{Li}$ is an executive director, deputy secretary general, of the Legal Linguistics Committee of China. 